\title{
Conflicts in Northern Ghana: Search for Solutions, Stakeholders and Way Forward
}

\author{
Edward Salifu Mahama and Felix T. Longi \\ Institute for Continuous Education and Interdisciplinary Studies \\ University for Development Studies \\ Tamale, Ghana \\ Email: edsalifu@yahoo.co.uk and longifel@yahoo.com \\ DOI: http://dx.doi.org/10.4314/gjds.v10i1\&2.7
}

\begin{abstract}
Ghana, compared to many other African nations, has been described as a peaceful and stable country. Nonetheless, there are several ethno-political and religious conflicts some of which have been ongoing in the country for several years. The conflicts could be broadly categorized as inter - and intra - ethnic conflicts. This paper gives an account of some of the major conflicts in Northern Ghana that have drawn national attention, most of which were/are violent. It examines the causes of these conflicts, some of which include the struggle for traditional power and supremacy, claims of ownership of land and politically and religious-motivated. While inter-ethnic conflicts are generally about sovereignty and claim to land, intra-ethnic conflicts are mostly about succession. The outcomes of these conflicts have made coexistence either very difficult in certain areas or even impossible. The analysis is based on a qualitative historical analysis of four case studies on the northern Ghana conflicts. Data were drawn from secondary and primary sources. Although earlier studies have taken this historical narrative form, it is also necessary to re-examine the cases on a comparative basis and to especially analyze the strategies that have been employed to manage, resolve or transform them. Understanding the dynamics of these interventions is necessary for the search for lasting peace. The paper also assesses the roles and involvement of major stakeholders in conflict management, resolution and prevention in northern Ghana and finally suggests a way forward.
\end{abstract}

KEY WORDS: Conflict, Ghana, Ethnic Conflicts, Power Struggle, Stakeholders

\section{Introduction}

For over two decades, conflict resolution and peace building have become topical issues in debates and discussions all over Africa. This is not only because of the recurrent and protracted nature of conflicts, but also because of their negative impacts on Africa's socio-economic and political developments as most of these conflicts are violent. Violent 
conflicts in Ghana are therefore not a peculiar case. In the West African sub-region, a number of violent conflicts occurred between 1982 and 2004. Some of these included conflicts in Liberia, Sierra Leone, Guinea and La Côte d'Ivoire. Though Ghana has been often portrayed as an island or oasis of peace in a sub-region otherwise characterized by violent conflicts, it is worth noting that at the national or local front, the story is different. For almost two decades, northern Ghana for example, has been a place of repeated ethno-political violent conflicts some of which have been reasonably well managed, thus bringing about relative peace in the areas concerned while others have degenerated into seasonal and/or annual 'rituals'. Some have in fact become protracted.

This paper compares four of the major conflicts in northern Ghana, two of which seem to have been resolved and the other two clearly unresolved despite the several years of interventions. The rationale for this study is to analyse the strategies that have been employed so far to manage, resolve or transform them as understanding the dynamics of these interventions is necessary for the search for lasting peace. The paper also assesses the roles and involvement of major stakeholders in the management, resolution and prevention of these conflicts and finally suggests a way forward. The design for this study was a qualitative historical comparative analysis, involving mainly questionnaires and interviews as tools of data collection. Secondary sources of information were also used. The presentation is in five sections including an overview of major northern conflicts in Ghana with a focus on the four case studies, analysis of the causes of the conflict, followed by a discussion of their effects and then presentation on a way forward which ends with a conclusion.

\section{Conflicts in Northern Ghana}

Conflicts are almost inevitable. Insofar as people interact with each other, disagreements and differences over issues would necessarily exist among them. These differences sometimes result into violent clashes. In Ghana, these conflicts are generally inter-ethnic (mostly land and political power); or intra-ethnic (traditional political power struggle, religious conflicts and partisan inclinations).

Ethnic conflicts have not just been between different ethnic groups such as the Konkomba/Dagomba in 1994 and Mamprusi and Kusasi since colonial time but also between different factions of the same ethnic group such as the Abudu and Andani of Dagbon in 2002 or between two candidates of the same ethnic group within the same community as in Chuchuliga in 2006.

Ghana has also had a number of religious conflicts though not as many as in countries such as Nigeria, Sudan or Mali. However, it must be stated that there has not been any violent clashes between Muslims and Christians. Nearly all the religious conflicts were clashes between factions of Muslims, mainly the Tijanniya and Al-Sunni (Seini and Tsikata, 2004; Mahama, 2010). 
Political violence is also a common phenomenon in Ghana. Seini and Tsikata again (2004) write that political violence between supporters of different political parties predates independence and has become part of the political scene since the anti-colonial struggle. In more recent times, political violence, though not exclusive, has been limited to the supporters of the National Democratic Congress (NDC) party and the New Patriotic Party (NPP).

For the purposes of illustration, this paper examines some cases of violent conflicts in northern Ghana in some detail by outlining the causes and attempts at managing and resolving them. These are the Bawku crisis, the Chuchuliga skin affair, the Konkomba request for paramountcy and the Dagbon crisis. These conflicts have been chosen because they were among devastating conflicts of northern Ghana. More interesting is that some of them were resolved and others were not. So this study compares the resolved to the unresolved ones for the way forward in the search for lasting peace in the conflict areas.

\section{The Bawku Conflict}

The Bawku crisis, which appears to be the first post-independence ethnic conflict in northern Ghana, is an inter-ethnic conflict between the Mamprusi and Kusasi of the Bawku area of the Upper East Region. It is essentially about who has traditional political authority over the people of Bawku and its surrounding communities. Since traditional authority is inextricably linked to control over land, conflicting claims of ownership of land in Bawku is part of the crisis. Although Bawku is a Kusasi town, like most towns and business centers of the country, it is cosmopolitan and made up of settlers of diverse ethnic backgrounds. However, the Kusasi as the dominant ethnic group claim traditional authority over the Bawku area. As a sequel to agreements made by the chiefs of the area in March 1931, which resulted in the election of the Bawku chief as head of all Kusasi, the Bawku Naba was recognized as the paramount chief of the area. This arrangement was part of the 1932 amalgamation of traditional systems prior to the introduction of the indirect rule system by the British (Ladouceur, 1979:55)

The genesis of this conflict dates back to the pre-colonial time. The Kusasi had always suffered from attacks by warring groups such as the Bisa and had sought support from the Nayiri of the Mamprugu Kingdom to fight the 'enemy' and provide protection for Kusasi traders who were at the mercy of the Bisa. During this period, Naa Atabia, who was the King and overload of Mamprugu, responded to the Kusasi request by sending armed Mamprusi fighters to protect the Kusasi and also to allow the safe passage of traders along the trade routes traversing the area (Syme, 1932:22). Naa Atabia established military/ trading posts in the most vulnerable communities, which were manned by the Mamprusi warriors. In due course, these armed care-taker Mamprusi royals, were appointed as chiefs over the communities they protected, namely; Bawku, Sinnebaga, Binduri, Teshi and Tanga (Hilton,1962). In Bawku, Naa Atabia made his son, Prince Ali, the chief and from then on Bawku chiefs have been of Mamprusi origin until in 1957 when the Kusasi, led by 
the Kusasi Youth Association, protested against the rule of the Mamprusi and demanded to be given the freedom to manage their own affairs.

The high point of the Kusasi agitation was in 1957 when the Mamprusi Bawk-Nab died paving way for a successor. There were a number of eligible candidates but three Mamprusi princes vied for the skin. The Nayiri chose Yeremiah Mahama to ascend the throne. While the Nayiri and his council of elders met in Nalerigu to enskin him, the Kusasi elders, apparently taking advantage of the disagreements among the Mamprusi contesting royals, also gathered in Bawku and selected Abugrago Azoka, a descendant of a Kusasi Tengdana (traditional priest) and prevailed upon him to undergo what could be described as an ad hoc installation ceremony organized by Kusasi Tengdana, using the chiefly regalia still in the possession of the Mamprusi princes. Hence, Yeremiah Mahama was replaced even before he could return to Bawku to undergo the second phase of the investiture. Clashes broke out soon after the parallel enskinment of Nab Abugrago Azoka.

The unsuccessful Mamprusi princes questioned the process of Yeremiah's nomination describing it as being at variance with established practices since the 1931 conference as the same time that they objected to the Kusasi action. At this point, technically there were two chiefs (Abugrago and Yeremiah) over one skin (the position of traditional ruler) creating an awkward situation. The Kusasi move received the endorsement or recognition of the then Nkrumah-led CPP government and as would be expected, this created misunderstanding, tension and uneasiness between the two ethnic groups as the new chief began to replace all the Mamprusi sub-chiefs with those loyal to him, mostly of the Kusasi ethnic group (Lund, 2003). Although the Mamprusi did not contest the issue of who was the first to occupy the lands in Bawku area, they were unprepared to relinquish traditional political power to the Kusasi. The government through the Acting Governor General took steps to resolve the impasse.

A Commission of Enquiry chaired by S.D Opoku Afari was set up to investigate the claims of both parties and make recommendations. The findings of the Afari Commission were in favour of the Kusasi claims as the rightful occupants of the Bawku skin. The Mamprusi appealed but were unsuccessful, making Abugrago Azoka the first ethnic Kusasi chief of Bawku. The Mamprusi became further infuriated by the elevation of the Bawk-Nab, in 1958, to a position of paramountcy, equivalent to the rank of the Nayiri, as this meant diminishing the authority of the Mamprugu overlord. In 1966, following persistent appeals by the Mamprusi, the National Liberation Council which overthrew Nkrumah and his CPP-led government reversed the situation, thus upholding the claims of the Mamprusi. This resulted in the dethronement Abugrago Azoka I and the enskinment of Adam Zambo, a Mamprusi. This remained the case until 1981 when the case came up again. The then government of the People's National Defense Council (PNDC) under the leadership of Flt Lt. J.J. Rawlings after examining the petition by the Kusasi, enskinned Abugrago Azoka II, son of Abugrago Azoka I, as Bawk-Nab in 1983 and since then Bawku has not known peace as there have been intermittent violent conflicts. The Kusasi blame the British colonial government for imposing Mamprusi rule on them in the name of aligning 
traditional authority with the pre-colonial traditional constitutions as a way of creating an organized and laid down system of Administration.

The Mamprusi on the other hand say that since pre-colonial days, the Kusasi had no chiefs and that they, the Mamprusi have always been chiefs of Bawku beginning with Prince Ali as the first Bawku-Nab. They claimed that Mamprugu was much bigger than now and that Kusasiland was part of their jurisdiction. They also blamed politicians or different governments, especially Nkrumah and Rawlings for aiding the Kusasi to gain traditional supremacy over them. The governments were seen to give or at least support the side seen to be their party supporters/sympathizers. For example, the governments of the National Liberation Council (NLC) and the Provisional National Defense Council (PNDC) took politically-motivated decisions in favour of factions perceived to be their sympathizers.

Both accounts have some commonalities. They have each indicated that the Kusasi are the occupants of Bawku and the Bawku area. They have also both stated that before the intervention of the British colonialists, the Kusasi did not have a chiefly system. The positions of chiefs do not only mean political control over the people but also authority to superintend over the appropriation of land.

Attempts at resolving this problem lies mostly in the hands of different governments. Other attempts by the Ghana Christian Council and the Centre for Peace and Conflict Transformation through arbitration have all failed, though their efforts have at least brought about some calm.

\section{The Chuchuliga Chieftaincy Affairs}

The Chuchuliga Chieftaincy Conflict is an intra-ethnic succession struggle over the Chuchuliga skin. It is the struggle by the people of Chuchuliga led by one of the royal gates, the Asangalisah Gate, which attempted to extricate itself from the control of an 'outsider,' the Sandem-Nab and overload and king of the Builsa. It is a struggle over the right of autonomy to choose their chief without the role of the Sandem-Nab. Chuchuliga, until 2006, when the upheavals began, had had two chiefs for many years; one elected in Sandema and recognized by the Sandema-Nab and the other elected by the people in Chuchuliga but not recognized by the Sandem-Nab, the overload.

Like the Bawku chieftaincy crisis, scholars have traced the causes of the Chuchuliga Conflict to the British Colonial Administration, which they say in their rush to implement the indirect rule system, placed Chuchuliga under the Sandema paramountcy with the Sandem-Nab as paramount chief. The reforms, which occurred in 1934, as part of the political amalgamation of traditional systems, were very much against the wishes of the people of Chuchuliga for two main reasons: their taboos were different and that there had been constant inter-clan warfare between Sandema and Chuchuliga prior to Colonial rule.

Even though a number of chiefs had reigned since the changes were introduced, it was during Nab Allan Asangalisa's tenure as Chuchuliga chief (Chuchuliga-Nab) that the 
problem surfaced. He was elected and enskinned in 1927, in Chuchuliga and witnessed by Nab Afoko, then the Sandem-Nab in line with the existing practice. In the 1950s, a serious rift occurred between Nab Azantilow, the then successor Sandem-Nab and Nab Allan Asangalisa. Nab Azantilow is reported to have wrongfully fined Nab Asangalisa two pounds and dismissed a number of his headmen for alleged disobedience. Nab Asangalisa challenged the then Sandem-Nab's actions. As a reaction to Nab Asangalisa's challenge, Nab Azantilow dethroned Nab Allan Asangalisa and unilaterally enskinned Aprime, as chief of Chuchuliga.

A Committee set up to investigate the case nullified Aprime's enskinment by pointing out that Nab Azantilow had no authority to dethrone the Chuchuliga-Nab since that is the prerogative of the king makers of Chuchuliga who enskinned him. The persistent resistance of the Chuchuliga chief to the authority of Nab Azantilow reflects the fact that the reforms were not carefully thought through before implementation. Though the Committee resolved the issue, Nab Azantilow was still aggrieved. As a result, when Nab Allan Asangalisa died, Nab Azantilow insisted that voting and enskinment be done in Sandema at his palace rather than the usual practice voting by households heads for contestants in Chuchuliga. Prince Francis Asangalisa, son of Nab Allan Asangalisa and one of the contestants disagreed with the idea and refused to present themselves in $\mathrm{Nab}$ Azantilow's palace for the voting. This generated a bone of contention between Nab Azantilow and the Chuchuliga people, especially those of the Asangalisa Gate.

Without Prince Francis Asangalisa, Nab Azantilow allowed the voting to proceed. This resulted in the election and eskinment of Nab Adakula Amaachana in Sandema as Chuchuliga-Nab. As was expected, Nab Amaachana faced a crisis of recognition in Chuchuliga. Matters became complicated when Prince Francis Asangalisa also got duly enskinned by the kingmakers of Chuchuliga in August 1995. From then on, until 2006 the Chuchuliga chiefdom had been ruled by two chiefs. In fact, Chuchuliga and Sandema came close to a full blown conflict when in late 1995, Nab Francis Asangalisa was ambushed and beaten up in Sandema, allegedly by Nab Azantilow's agents, when he was spotted in Sandema dressed in chiefly regalia. There were reprisal attacks in Chuchuliga resulting in the burning of Nab Amaachana's house by Asangalisa supporters, when news got to them.

Between August 1995 and December 2006, a number of attempts were made to resolve the impasse beginning from the Upper East Regional House of Chiefs in Bolgatanga through the National House of Chiefs to the Supreme Court in Accra. Nab Francis Asangalisa was the main complainant. After examining the available documents and submissions of both parties, the Regional House of chiefs finally upheld the findings of the earlier Committee which nullified the enskinment of Nab Amaachana but fell short of rebuking the paramount chief of Sandema, Nab Azantilow, for imposing an illegitimate candidate on the Chuchuliga chiefdom. In July 2006, citing peace but perhaps faced with the lack of support and recognition by his peoples, Nab Adakula Amaachana voluntarily abdicated and reconciled with Nab Francis Asangalisa. That singular act by Nab Amaachana brought to an end to the over a decade long chieftaincy succession conflict. The insistence of the 
Asangalisa Gate to be allowed to choose their chief in their own town could perhaps be described as an act aimed at democratizing chieftaincy. But it also sent a strong message that it was no longer tolerable for the paramountcy to meddle in the internal affairs of any community no matter its size. Perhaps this crisis did not drag on for long because it was not politicized.

The contest in this conflict is clearly a case of self-esteem in the case of Nab Adakula Amaachana and abuse of power in the case of Nab Azantilow. Yet, the relatively simple resolution could be attributed to the clear definition of the problem. More causes of the conflict would have made it more complicated and difficult to resolve.

\section{The Konkomba Request for Paramountcy}

The Konkomba are one of the ethnic groups of northern Ghana. They are mainly in the north-eastern corridor of the Northern Region. They are mainly farmers, consequently, many of them live in remote, rural areas where they can find vast farm lands. They are surrounded by other ethnic groups such as the Dagbamba, Anufo and Bimoba.

The Konkomba demand for paramountcy has a long history which dates back to the latter part of the $19^{\text {th }}$ century when the Konkomba were under the authority of Ya Naa, the king of Dagbon. The conflict essentially revolved around resentments based on political exclusion. Mahama (2003:181) explained that "when George Ekem Ferguson visited Yendi in 1892 to sign a treaty of trade and friendship on behalf of Great Britain with the Ya-Naa, he recorded the fact that the Konkomba were under the authority of the Dagomba ... The Konkomba were not recognized as a separate people who had an independent existence." This implies that even what was their land was not demarcated for them. The British identified chiefly groups and put the non-chiefly ones under their rule. Relationships between such groups were cordial for several years but in the last twenty years, most of these groups including the Konkomba have questioned their status as subjects to the chiefly ones (Awedoba, 2009, Mahama 2003, Martinson, 2002 ). The Konkomba claim that Eastern Dagbon was largely occupied by them and allied ethnic groups until the Dagbamba came in, conquered the indigenous people, claimed ownership and took control over the area (Talton, 2003; 2010). The colonial leaders formally established power for the Dagbamba to regulate, sanction, and restrict the activities of the Konkomba. It was clear that this power vested in the Dagbamba was seed sown for future conflicts.

In view of their "subordinate status," the Konkomba claimed they were expected to fulfill certain obligations such as payment of taxes and offer compulsory labour to support Dagbon chiefs, which they initially obliged. The Konkomba Youth Association (KOYA) began to question this requirement. These Konkomba agitations against "the chiefly groups, resulted in the war with Nanumba in 1980" (Brukum 2001: 9) and with the Dagbamba in 1994. The Konkomba did not only want to have a paramountcy at the rural level but also at the Northern Regional House of Chiefs, where their voices could also be heard. This expectation led to their official petition that the Saboba chief be elevated 
to the status of paramountcy (Mahama, 2003). What this implied was a rejection of the subjugation of the Dagbamba and a demand for self-rule.

After several meetings with their chiefs and elders, KOYA on behalf of the Konkomba wrote a petition in June 1993 to the National House of Chiefs to formalize their request for the creation of Paramountcy for the Konkomba Kingdom, which would be known as 'Ukpakpabur'. What this implied was that the Konkomba would want a well demarcated piece of land which can be divided into traditional councils. Mahama (2003:13 - 14) writes: "Simply put the nitty-gritty of the Konkomba petition was for the creation of a paramount chief and a traditional council for all the Konkomba in Ghana, a right to live in a clearly defined area of their own and finally grant to them traditional independence." Freedom to practice their culture and the right to feel like human beings were implied in their request (Maasole, 2011).

Respondents indicated that sometimes their festivals were disrupted by the Dagbamba. They said also that the Konkomba were often not welcome in gatherings where the Dagbamba were in the majority. The granting of paramount status implied that the Konkomba would no longer go to Dagbon chiefs for arbitration and settlement of their cases. Some other reasons for their demand, according to Konkomba respondents, included numerical strength, domination of the chiefly groups in the politics of the Northern Region, freedom to practice one's culture and the right to human. Their claim of having higher numbers did not reflect in 2000 Population and Housing Census data of the Ghana Statistic Service. The figures were 305,575 for the Konkomba and 594, 865 for the Dagbamba.

The demand for paramountcy created a rift between the Dagbamba and the Konkomba. While the Konkomba conceived it in terms of their right to self-rule and ethnic identity, the Dagbamba, "their overlords," interpreted it not only to mean an uprising against their authority but also a demand for Dagbon lands. Above all, the Dagbamba perceived this demand as a reduction in their status. The status of a King depends on two things: political authority (people under his rule) and the size of landmass controlled. If the Konkomba succeed in their request, the Dagbamba would lose their lordship over them or at the least, be of equal traditional status with them. Knowing the unstructured nature (non-hierarchical), it was difficult for the Dagbamba to see the establishment of a parallel chieftain of equal status to theirs. Hence, the Dagbamba interpreted the Konkomba demand as one of having a hidden agenda and therefore called for an explanation of the Konkomba new move.

The National House of Chiefs referred the petition to the Ya-Naa, who according to the British apportioning of minority ethnic groups, had the sole responsibility of granting this request. In his response, the Ya-Naa invited the Konkomba chiefs and elders who had signed the document to find out if they were the real signatories to the document and if they accept responsibility of what they signed. Indeed, they accepted responsibility but the Ya-Naa refused to endorse the request for a number of reasons. He did not agree that 
the Konkomba were the largest ethnic group in the Northern Region. He did not also think that the Konkomba were just asking for an elevation for their chiefs but an attempt to claim Dagbon lands. But the pressure to give paramountcy to the Konkomba grew and finally became one of the major reasons for the 1994 conflict (Mahama, 2003).

Some Dagbamba respondents say that eventually in 1995, the Ya-Naa gave in to thl2e external pressures and elevated three Konkomba chiefs to the status of paramountcy. The new move of the Dagbamba King was probably a response to not only the pressures of the Konkomba but to the concerns raised by the Ghanaian public and the House of Chiefs who thought it was time to grant the Konkomba their independence.

The Konkomba paramouncies were the Saboba, Sanguli and Nambiri chieftains. They added that this resulted in internal conflict among the Konkomba because it was difficult for the Konkomba to decide on which chief should be at the helm of affairs and how the new system was going to rotate among the different chiefs. This ended up creating an intra-ethnic conflict as the three main chiefs did not agree to share power. The problem grew worse and eventually the Konkomba were left just in the same situation as they were before their petition.

\section{The Dagbon Crisis}

Dagbon means the land of the Dagbamba. The traditional capital is Yendi, where their kings reside. They are believed to claim and occupy an area of about 8,082 square miles (Martinson 2002). Dagbon history has been marked with misunderstandings and noncompromising stances with regard to chieftaincy succession disputes.

The crisis in Dagbon is one of succession. It is about getting the rightful person to occupy the position of King, the Ya-Naa. They use a "gate system" (rotational system) which became operational after the death of Ya Naa Yakubu I (1829-1849). This meant that his three sons: Abudu, Andani and Mahami by custom, would be the immediate ones to take over the throne in turns. Unfortunately, Mahami died prematurely leaving the competition to Abudu and Andani. The two then became the gates and continued after the death of Naa Yakubu I, in turns, sometimes with violent clashes between them. They however managed the problem until the enskinment of Ya-Naa Mohammadu Abudu IV from the Abudu Gate in 1974. The Andani protested saying it was not the turn of the Abudu and Naa Mohammadu Abudu should be dethroned and replaced by one from the Andani gate. The then ruling National Redemption Council (NRC) Government, under Col. I. K. Acheampong, set up a Commission of Inquiry to look into the matter. At the end of its work, the Commission recommended that an Andani chief should replace the already enskinned Abudu chief. This was executed and Naa Yakubu Andani IV was enskinned to replace Naa Mohammadu Abudu IV. There was controversy over this change as the Abudu did not agree with the government's decision. The Abudu Gate initiate court appeals but they were overruled. All the respondents claimed that the Dagbon dispute was deepened 
as the divisions took on political forms and depending on which political party was in office, the feuding factions got support or not.

The dethroned king, Naa Mohammadu Abudu IV died later in 1988 and was buried. The Abudu considered him a former King and as such insisted that customarily his funeral had to be performed in the Gbewaa Palace (Ya-Naa's palace) but this was not done. The Abudu were unhappy about this and waited for an opportune time to ask for this to be done. When the New Patriotic Party (NPP) came to power, factional fighting (Abudu and Andani) broke out in Yendi, resulting in the killings of several people including Ya-Naa Yakubu Andani IV, the then overlord of Dagbon and his elders and family. Many houses and property were also destroyed. It started with intermittent exchange of fire on 25th March 2002 till $27^{\text {th }}$ March 2002 and got to the peak when the King's palace was set ablaze. The Andani claimed that the Abudu marched on till they entered the palace killing anyone they met including the Ya-Naa, the King. They further bemoaned the fact that the King was not just killed but dismembered. This conflict also caused some fighting between the Andani and Abudu in other Dagbamba towns and villages resulting in the death and loss of property.

The immediate cause that sparked off the conflict was the beating up of one Ziblim from the Andani Gate. Ziblim was allegedly sent by his father Madugu to invite the Duguwulana for the celebration of the fire festival. On his way, he was beaten up by youth from the Abudu Gate. The Abudu claimed they beat him and destroyed his bicycle because he came to their section of the town purposely to make fun of them. This was followed by retaliation from the Andani, who shot one Abdulai of the Abudu gate. The beating of Ziblim and the shooting of Abdulai became the immediate reasons for the exchange of fire. Remote reasons included the replacement of Ya Naa Mohammadu IV from the Abudu Gate with someone from the Andani Gate and the delayed funeral of Mohammed IV (Mahama, 2003).

Respondents from both sides indicated that political interference was also another reason. While the Abudu accused the Andani of bringing mercenaries to fight for them, the Andani accused the Abudu of enjoying government (NPP) support. The Andani alleged that the police, army and other security agencies joined the Abudu to fight them because respondents said that the army failed to come to the rescue of the Ya-Naa when he requested for the Mowagand. The consequences are the widening gap between the gates. It has since been difficult to work out a favourable or mutually acceptable way forward for both groups as each side has taken an entrenched position.

A number of attempts were made by different governments to resolve the conflicts between the two factions. The NPP, which led ruling government, at the time of the outbreak, set up the Wuaku Commission to investigate the matter after which a group of eminent chiefs include the kings of Ashanti, Mamprugu and Gonja continued the process of reconciliation. The NDC also invited the two factions in 2013 to meet and discuss the way forward for the crisis. 
As part of the resolution process, the Commission recommended that the identified killers of the Ya-Naa be arrested and prosecuted. It also recommended that the funeral of YaNaa Mohammadu Abudu IV, who died in 1988, be performed in accordance with Dagomba custom. As at the time, the body of Ya-Naa Yakubu Andani was still not buried so it was recommended that the body still be preserved till it was time for it to be buried according to Dagbon custom. It finally advised that the actual implementation of some of these recommendations should be informed by further investigations. The Commission also asked the ruling NPP government to address the security lapses that were exposed during this conflict.

In the meantime, since the conflict was not solved, other efforts were being made by different groups. The Catholic Diocese of Yendi has organized and continues to find ways to engage the factions in dialogue.

\section{Causes of the Four Conflicts}

The knowledge and understanding of the causes of conflict is important and necessary for determining the most appropriate approaches and strategies for conflict resolution and transformation. A number of causes stood out clearly in all four conflicts. They are all about power and supremacy and the rejection of that power by those regarded powerless. The claims of superiority stirred up the inter-ethnic conflicts between Konkomba and Dagbamba and between the Mamprusi and Kusasi Conflicts. The Dagbamba claimed superiority over the Konkomba while the Mamprusi did same over the Kusasi.

Even in the case of intra ethnic conflict the power struggles were underpinned by supremacist sentiments. In the Chuchuliga case, the Sandem-Nab's claimed supremacy by expecting the people of Chuchuliga to succumb to his directives no matter how misplaced. The Sandem-Nab broke traditional protocol to have his way by installing a chief outside of his community he still did not expect the people of Chuchuliga to challenge his decisions because he is the paramount chief. Although the situation was a bit different in the Dagbon case as it was not directly about the powerful and powerless but it still was a power struggle. It had to do with traditional power and the reigning king assuming the position of the powerful.

The genesis of three of these conflicts (Konkomba/Dagomba Mamprusi/Kusasi and Chuchuliga) has been traced to the colonial policy of indirect rule with its attendant practice of giving power to chiefly groups to control the non-chiefly ones without recourse to the traditional jurisprudence. However, in this case, the Chuchuliga Affair was slightly different. Its colonial influence was one of subsuming the non-chiefly under the chiefly but one of upgrading one chieftain over other chieftains.

The excessive use of power by chiefs was another cause. The Chuchuliga Affair and the Konkomba-Dagbamba case are two clear examples. The Sandem-Nab interfered in succession disputes between the royals of Chuchuliga by over-stepping his traditional 
powers to change the playing field. His action to move the contest from Chuchuliga to Sandema escalated crisis and even defamed his elected candidate. Similarly, the Dagbamba chiefs were accused of taking decisions about the Konkomba land without consulting them. The Dagbamba did not think that it was necessary to consult their "subjects," even when the Ya-Naa was assigned the duty to settled the case on the Konkomba request, he made the decision of rejecting their request with consultations.

The lack of State or institutional mechanisms for the management and resolution of such conflicts had also been a contributory factor, especially for the Dagbon and Bawku crisis. Though Committees were set, which investigate and submitted findings made, these were emergency-response measure. Today some modicum of structure exist in the form of the Regional Security Committee (REGSEC) and District Security Committees (DISEC), whose role is to provide constant surveillance and mobilize the request action in the face of conflict real or potential this was not always the case.

\section{Effects of the Conflicts}

The effects of these conflicts are similar except for the Chuchuliga conflict. In all the remaining three conflicts, as would be expected in violent conflicts, there was loss of lives and property, sour relationships between the Kusasi and Mamprusi, Dagomba and Konkomba, and Abudu and Andani. These sour relationships have since created suspicion between them. There is generally slow socio-economic development and low productivity in all their livelihood endeavours due to fear hence people on both sides are unable to go back to their normal duties fully.

Government workers were afraid to accept postings to Bawku and Yendi. A good part of the monies that could have been used by the government to develop the areas has been spent on security. It is estimated that about one million Ghana cedis (ten billion old cedis) has been spent on security annually to maintain peace in Northern Ghana alone (Awedoba, 2009). Because the Chuchuliga conflict was less violent, not many lives were lost and property destroyed. This was however not the same of the three others which involved feuding factions engaged in direct armed struggles. Although the relationship between the Sandem-Nab and the Asangalisa was sour, normalcy was restored when the dispute was resolved.

\section{In Search for Solutions}

Different actors have been involved in the search for ways to manage and/or resolve the above conflicts. They include the disputants, traditional authorities (TAs), Government of Ghana (GoG), Centre for Conflict Transformation and Peace Studies (CECOTAPS), Christian Council of Ghana (CCG), Council of Eminent Chiefs(CEC) and West African Peace Network (WANEP). 
Although different stakeholders were involved, strategies used were basically the same: mediation, arbitration and adjudication. In the Chuchuliga case, the measures employed included settlement at the Regional House of Chiefs, the paramountcy in Sandema and the High Court. None of these solved the problem until one of the contestants decided to withdraw from the contest. The brought the peace eventually.

In all four conflicts, traditional authorities were used. These were traditional authorities of the same ethnic group as in the case of the Chuchuliga and Dagbon cases, where there was arbitration. Traditional authorities from outside the ethnic group as in the use of the CEC for the Dagbon crisis were also involved in the disputes. The two conflicting factions of Dagbon are being led to consider a peaceful compromise settlement. There are mediation talks or workshops that have been organized by faith-based institutions such as the CCG and CECOTAPS. They have organized workshops aimed at helping to settle Mamprusi-Kusasi matter while the Catholic Diocese of Yendi has been involved in the Abudu-Andani issue. These talks too have not resolved the problem although one could say they have contributed to the relative peace in Bawku and Yendi.

The GoG has also been directly or indirectly involved in all the violent conflicts in the country. It has been involved in ceasefire efforts in all violent conflicts. In the Dagbon crisis in 2002 and the Kusasi-Mamprusi conflict in Bawku in 2001 and 2009 such efforts were a little late, thus allowing major losses on each warring sides. Alongside, the ceasefire initiatives were peacekeeping efforts, where the armed police and military task forces were deployed to the conflict zones for substantive for periods. To date the army maintains a base in Bawku.

In its efforts to manage or even resolve some of these conflicts, the Gog has set up some Committees or Commissions of enquiry. The Afari Commission of Enquiry that was chaired by S.D. Opoku Afari was set to investigate the Mamprusi - Kusasi conflict while the Wuaku Commission investigated the Dagbon case. The main problem with the reports of the committees and commissions in these cases is that the recommendations of the reports were not fully implemented, thus defeating the very objective for which they were set up. The conflicting factions sometimes refused to accept the findings of such reports rendering it impossible for the GoG to move to the next stage. Further analysis of this approach, especially in the cases of Bawku and Dagbon crises shows that even if they implemented the recommendations by punishing perpetrators, they did not address the underlying problems that led to the conflicts.

\section{Way Forward}

Just as there have been an increasing number of both violent and non-violent conflicts in the last two decades in many places in northern Ghana, so must there be different approaches to managing and resolving them. The following are some suggestions regarding the way forward. 
Every ethnic group in Ghana has traditional means of managing, resolving or even preventing conflict, mainly through the use of community or ethnic leaders. This traditional strategy makes use of leaders from the individual ethnic group and/or other ethnic groups. These means are mainly through negotiation, mediation and arbitration. Many of such traditional methods have failed, especially in cases of violent conflicts. This is because what made the indigenous ways of resolving conflicts effective have been tempered with by the social changes that are taking place in the country (Tsikata and Seini 2004). These factors pose many challenges to modern conflict resolution. In days when these strategies worked, conflicts did not end in mass destruction of property and loss of lives because of the then use of less sophisticated weaponry.

The people also believed strongly in the spiritual implications of the outcome of mediations. The gifts or fines, which included kola nuts, fowls, goats, and drinks, were meant to appease the gods of the earth and undo all curses, hence cleansing the society and land. It is therefore important that the GoG and, in fact, African governments in general and their development partners seek means by which the relevant aspects of the conflict management systems of the indigenous communities can be synthesized with those of the modern states in order to harness the potential benefits of both systems. Integrating local actors in conflict resolution with regional and global institutions is needed more than ever to create the needed peace.

There should also be a concise documentation of succession patterns. Where these exist, all parties must be involved in the production of the document after which adherence must be enforced. The Chuchuliga case exemplifies the need for this. The harsh realities of the aftermath of conflicts and the role of conflict in retarding development have become a challenge to development partners. It is evident that if they have to achieve their objectives and aims, then there will be the need to include conflict management in their development agenda and to draw up strategic action plans for conflict management in the country. It will also be necessary to consider sponsorship of research and studies in conflict, support centres and institutions that generate data, offer counseling and train local populations on conflict management skills/techniques in the wake of the modern day challenges.

There is also the need for constant and continuing assessment of conflict resolutions and peace mitigating strategies. Stakeholders must be ready to step back to see what they have learned from their involvement in conflict management or resolution. Did they achieve what was set out to be achieved? If yes, why and how was it done? If they failed they can ask the same questions of why and how.

From the above discussions of the four conflicts, one can also say that managing or resolving conflicts needs to involve as many different people from different sectors of society and approaches as possible. All factions must be brought to the table of resolution at some point. However, it is also important to draw from both local and external sources 
and especially stretch the net as wide as possible especially in the case of the violent conflicts of northern Ghana.

There is the need to appreciate the fact for peace and reconciliation to happen, conflicts must be viewed as not mere events. Lederach (1995) argues that conflict is not a short term phenomenon that can be resolved permanently through mediation or other intervention processes. Instead, he suggests that the consequence of violent conflicts can be transformed (as it changes events, people and their relationships) so that self-images and social relationships improve as a result of conflict instead of being harmed by them. This must happen at both the individual and systemic levels. At the personal level, conflict transformation involves the pursuit of awareness, growth and commitment to change. The disputants at individual levels must want to resolve their problem. This may occur through the recognition of fear, anger, grief and bitterness. These emotions must be outwardly acknowledged and dealt with for effective transformation to take place. At the systemic level, the process must aim at increasing justice and equality in social systems as a whole. This is a process-based peace building strategy which allows disputants to learn through practice to prevent the re-occurrence of conflicts and to take ownership of the process. Depending on the type of conflict, the social organization(s) of those involved must be used as means to address the issue. For example, if it were a chieftaincy dispute, it would be important to ensure that the succession line or rotations are well structured to ensure fairness and equal opportunity to the right candidates.

The different governments that come to power must be committed more than ever to peace building and should therefore not interfere in conflicts by taking sides. When commissions or committees are set up, governments must endeavour to implement their findings and recommendations as much as possible. In line with that, the National Houses of Chiefs should create access to the ethnic groups that are not represented at the Regional Houses of Chiefs so as to allow them to participate in deliberating on matters affecting the development of the region and country as a whole.

Due the costs involved in resolving conflicts, it would be necessary to build consensus and mobilize concerted efforts. Organisations and institutions involved in peace efforts must of necessity work together to draw in their strengths as they tackle conflicts. It is even more important to keep communications flows and avoid the creation of suspicion and compromise. The use of alliances, coalitions and networks such as the Sustainable Peace Initiative and the Northern Peace Network has been useful.

Finally, there is also the need to adhere to the 1992 Constitutional provisions on chieftaincy, which places chieftaincy matters strictly under the ambit of the National House of chiefs, thus insulating it from governmental control or interference. The lessons learned from governmental attempts to resolve the Bawku crisis through one legislation or the other are clear testimony of their ability to stir up further crisis especially under out current situation of heightened partisanism. 


\section{Conclusion}

it is evident from the four cases that although people may maintain their ethnic identities, their attitudes and perspectives change. People who earlier thought it was no problem to be subsumed by other groups have come to demand rights of identity and self-rule latter such as the case of the Konkomba. Also, the intra-ethnic cases in this study expose some weakness of the traditional and customary system of leadership. The Dagbamba in the Dagbon crisis were unable to use their structures to resolve the problem. In contrast, the Chuchuliga one was solved, though with initial resistance. This raises questions about chieftaincy and the perceptions of power. It is clear from the Chuchuliga example that it is the local people themselves who can solve their problem as outsiders for different reasons may complicate the situation. The Chuchuliga case also suggests that when the reasons for a particular conflict are well defined or few, the chances of resolving the problem become high. The Bawku and Dagbon cases have been linked to too many causes, especially when conflicts are politicized. Consequently, it has been difficult to deal with all the causes satisfactorily.

Conflicts are very linked to the environment and culture of the people in dispute. As a result, it is very difficult to prescribe specific approaches and strategies to be used to resolve or manage them. Particularly, if it is generally accepted that the causes of conflicts are multiple due to varying situations, the approaches and strategies to deal with them cannot remain the same. Multiple and more creative approaches are required to respond to and transform conflicts. This will not happen through repetitive ways of using normative techniques of conflict resolution. Three conflicts in this study have remained unresolved because of this. In-depth studies of various approaches are required to understand the dynamics in order to apply appropriate strategies.

\section{References}

Amoo, S.G. (1997). The Challenge of Ethnicity and conflicts in Africa: The Need for New Paradigm, New York, Emergency Response Division: United Nations Development Programme

Awedoba, A.K. (2009).An Ethnographic Study of Northern Ghanaian Conflicts: Towards a Sustainable Peace Accra, Sub-Saharan Publishers.

Bawi, K.N. (2003). “An Indigenous Philosophical Context for Conflict Management."

http://www.info.worldbank.org/afrik.default.htm accessed 23/10/2013

Bhaskaran, M.W. (2003). "Role of Academics in Conflict Resolution

http://www.mkgandhi.org/nonviolence/academics.htm 
Bombande, E. (2007). "Conflicts, Civil Society Organisation and Community Peace Building in Northern Ghana." In Tonah, S. (Ed) 2007.Ethnicity, Conflicts and Consensus in Northern Ghana. Accra: Woeli Publishing Services, pp. 196-228

Boulding, E. (1990). Building a Global Civic Culture Education for an Interdependent World. New York, Syracuse University Press

Brukum, N.J.K. (2007). "Chieftaincy and Ethnic Conflicts in the Northern Region of Ghana." In Odotei, Irene K. and Albert K. Awedoba (eds.). Chieftaincy in Ghana: Culture, Governance and Development. (429-448). Accra: Sub-Saharan Publishers (2001). The Guinea fowl, Mango and Pito Wars. Episodes in the History of Northern Ghana. 1980-1999. An Inter faculty Lecture, University of Ghana, Legon-Accra: Ghana University Press (1992).“Gonja-Nawuri Conflicts. An Overview” UHURU No.5

Coser, L.A. (1965).The Functions of Social Conflict. London: Routledge/Kegan Paul Limited

Hilton, T.E. (1962). "Notes on the history of the Kusasi", Transactions of Historical Society of Ghana, Vol. vi, 79-86.

Lederach, J. P. (1995). Preparing for Peace: Conflict Transformation Across Cultures. Syracuse, NY: Syracuse University Press.

Martinson, H.B. (1994). The Hidden History of Konkomba Wars in Northern Ghana. Accra: Matta Press.

- - - - (2002). Dagbon: Who killed Ya Na Andani Yakubu II...? The historical Antecedents of the Yendi Skin Affair. Accra: Sundel Services.

Mahama Ibrahim (2003). Ethnic Conflicts in Northern Ghana. Tamale, Cyber Systems.

Maasole, Cliff (2011). The Land Factor in the Konkomba-Nanumba Crisis. Ghana Journal of Development Studies, Vol. 8(1). 33-49

Mensah-Bonsu, H.J.A.N and Effah, P. (2003). Conflict Management and Resolution Skills Accra: National Council on Tertiary Education

National Architecture for Peace in Ghana (2006). (Abridged version) Sponsored by UNDP

Ninsin, K.A. (1995). “Conflict In Pursuit of Liberty”. In Quaye M. (Ed) 1995. Democracy and Conflict Resolution in Ghana. Accra: Gold Type Publications Ltd .

NRG8/2/214, Syme, J.Y.G. (1932). The Kusasi: A brief history 
Report of the Opoku Afari Commission of Inquiry into the causes of MamprusiKusasi Ethnic clashes, December, 1958.

Talton B. (2003). Ethnic Insurgency and Social Change: A History of Konkomba of Northern Ghana. Unpublished PhD thesis, Chicago University.

..............(2010). Politics of Social Change in Ghana: The Konkomba Struggle for Political Equality. New York: Palgrave Macmillan.

Tsikata, D. and Seini, W. (2004). Identities, Inequalities and Conflict in Ghana. CRISE Working Paper 5 , November 2004.

Wuaku Commission Report (2002). Report of the Commission of enquiry, Yendi Events. C.I. $36 / 2002$ 